$\left.\begin{array}{c}\text { INTERNATIONAL JOURNAL OF } \\ \text { ORGANIZATIONAL LEADERSHIP }\end{array}\right) \begin{gathered}\text { INDUSTRIAL } \\ \text { MANAGEMENT } \\ \text { INSTITUTE }\end{gathered}$

\title{
Implementation of Learning Organization Components in Ardabil Social Security Hospital
}

\author{
Azadeh Zirak \\ Department of Management, Ardabil Science and Research Branch, Islamic Azad University, Ardabil, Iran. \\ Department of Management, Ardabil Branch, Islamic Azad University, Ardabil, Iran
}

\begin{abstract}
Keywords:

Learning Organization, Organizational Learning, Organizational Learning Management, Knowledgebased Learning System, Knowledge Management

Correspondence:

za_zirak313@yahoo.com

This study aimed to investigate the implementation of learning organization characteristics based on Marquardt systematic model in Ardabil Social Security Hospital. The statistical population of this research was 234 male and female employees of Ardabil Social Security Hospital. For data collection, Marquardt questionnaire was used in the present study which its validity and reliability had been confirmed. Statistical analysis of hypotheses based on independent samples t-test showed that learning organization characteristics were used more than average level in some subsystems of Marquardt model and there was a significant difference between current position and excellent position based on learning organization characteristic application. According to the research findings, more attention should be paid to the subsystems of learning organization establishment and balanced development of these subsystems.
\end{abstract}

(C)AIMI Journals

\section{Introduction}

Learning at the system level provides not only the best chance of survival but also an opportunity for success. It is better for organizations to recover quickly and learn more from both their failures and successes to build and maintain the competitive advantage adapting to new situations. These organizations need an environment for their continual change to become a learning organization; an environment in which groups and individuals are 
constantly engaged in new learning processes (Marquardt, 2002). Owen (1991) stated that the main purpose of business was to create a profit and a product in the past, but now is to become an effective learning organization. This does not mean that the products and profits are no longer important, but it means that they would be impossible to achieve without continuous learning. If an organization does not adapt itself to suit the continuously changing environment through quick and effective learning, it will not be able to survive. In fact, external environmental changes can lead to adaptation or extinction of organizations over time. Accordingly, transforming organizations into learning as a fundamental move is a response to these changing situations and requirements (Marquardt, 2002). Therefore, organizations can better understand why changes occur, analyze them to identify findings, and adapt themselves best to their environmental changes. The main aim of this study was to investigate the implementation of learning organization characters based on Marquardt systematic model in Ardabil Social Security Hospital. This paper clarifies the distinction between organizational learning and learning organization and provides a summary of common different learning organization models. Furthermore, it justified the research hypotheses and results in result and discussion sections.

\section{Organizational Learning}

In the early 1970s, the concept of organizational learning systems is proposed and developed. Individuals' learning within the organizations is called organizational learning which enables them to cope with changing tasks, technologies, and environments. From experts' perspective, organizational learning is an opportunity to make changes and keep pace with the dynamically changing environment (Conner, 1992). This highlights that organizational learning is a fundamental factor in prompting innovation and creativity.

Brown and Duguid (1991) considered learning as an essential bridge between working and innovating. Also, interdependent processes of learning and creativity and innovation can be viewed as two sides of the same coin. Creativity and innovation are considered as crucial learning skills for growth which can influence organizations at different levels (Rahnavard, 2000). The process of learning is influenced by a broad set of social, political, and structural variables. This process involves sharing knowledge, beliefs, and assumptions among individuals and groups (Argyris, 1999). Learning and organizational learning are prerequisite to contingency approach to managing which demonstrate organization's ability to behave in 
the new way in new situations (Dodgson, 1993). Fiol and Lyles (1985) defined organizational learning as the process of improving actions through better knowledge and understanding. Yang, Watkins, and Marsick (2004) linked learning enablers in an organization to learning outcomes such as organizational knowledge and organizational performance. This shows that neglect of individual, group, organizational-level outcomes could lead to the fundamental incapability in detecting intended learning outcomes (Jyothibabu, Ayesha, \& Bibhuti Bhusan, 2010). Each organization at every stage of its development and implementation can eventually move on to learning (Garavan, 1997).

\section{Learning Organization}

Over the past few decades, learning organization has attracted much attention in the field of training and development which have the highest usage in the field of organization and management studies (Sobhaninezhad, Shahaei, \& Youzbashi, 2006). Today, learning organizations continuously strive to achieve a common understanding of teamwork including organizational continuous improvement, multitasking, quality management, and organizational learning teams (Marquardt, 2002). Garvin (2000) has defined learning organization as organizations' skills and abilities to create, acquire, transfer, share knowledge, and modify organization's behavior to describe the knowledge and new insights.

Sharman (2005) stated that management in a learning organization is different from management in a traditional organization because in these organizations the managers are designers, teachers, and principle-oriented people. Furthermore, the collaborative effects in establishing such kind of organizations were proved to be the learning organizations' components. In these organizations, all people normally involve in identifying and problem solving and thereby the organizations can acquire new experiences, improve organizational affairs, and increase their abilities. Solving root problems is the main value of the learning organization, while traditional organizational structures were designed to maximize efficiency and profitability. In learning organizations, staff is trying to identify the problems and seek for understanding customers' needs (Daft, 2007, 2008).

Therefore, employees can correctly identify their organization's strategic directions which were not simply possible in the previous years. The staff identify customers' needs and develop strategies based on the teams' activities which provide good customer services. These innovative strategies have consistency with the overall organizational and employees' objectives and thereby the staff try to improve the performance of the whole organization. 
Considering their organization's mission, different sections of learning organizations attempt to adapt themselves to the rapidly changing environment and welcome some changes in the environment. In learning organizations, most decision making authorities are delegated to individuals. Delegation is basically a way for organizations to distribute the authority to operate to all levels of the organization from top to bottom.

The key elements of learning organization are all members of specialized unites or business-unit teams. Learning organization is an organization where individuals' expand its new skills or ideas to create the results it truly desires (Senge, 1990). In these organizations, new and expansive patterns of thinking are nurtured, collective thinking and learning is promoted, and people are continually learning how to learn together.

\section{Learning Organization Model}

Since the early 1990s, various theories about learning organizations have been proposed by organizational theorists. Furthermore, some scholars tried to check the concept of learning organizations practically besides the theoretical discussions through designing conceptual models and their implications in the real environment of organizations. One of these models is Marquardt systematic model. According to this model, four influential factors including people, technology, knowledge and organization in the role of subsystems, and learning process in the role of main system were recognized. Each aspect is analyzed based on a series of indices in terms of their roles in the main subsystem of learning. In the subsystem of people, managers, employees, customers, suppliers, sellers, contractors, partners, and society are studied. In organization subsystem, perspective, culture, structure, and strategy are studied. In technology subsystem, knowledge management, accessibility to information, and information exchange are investigated. Finally, in knowledge subsystem, knowledge generation and knowledge management, storing, analyzing, and exploring data are studied.

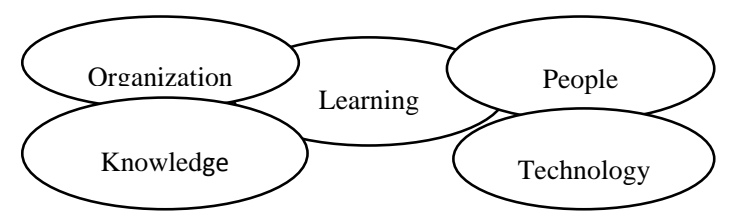

Figure 1. Learning organizational systematic model based on Marquardt systematic model

Marquardt (2002) asserted that an organization becomes learning when new behaviors are rooted in social norms and common values. Moreover, he believed that it is necessary to implement the following ten strategies to build learning subsystem, namely develop modular 
and reusable learning plans, increase people's capability to learn how to learn, develop organizational dialogue, design development plans based on employees' capability, design self-grooming plans, execute systemic learning skills, encourage and execute systemic thinking approach, use scenario planning for learning, expand domestic and universal intercultural mindsets and learning, and finally increase employees' intervention and contribution .

To propose a conceptual model of organizational learning capability for balanced development of organizations, Naderi Khorshidi (2002) conducted a study with a systematic and comprehensive view in Iran Khodro Company. The results revealed that there was a correlation between evaluating organizational success and capabilities of organizational learning and there was a significant difference between the existing and good conditions of this company in terms of organizational learning in competitive situations.

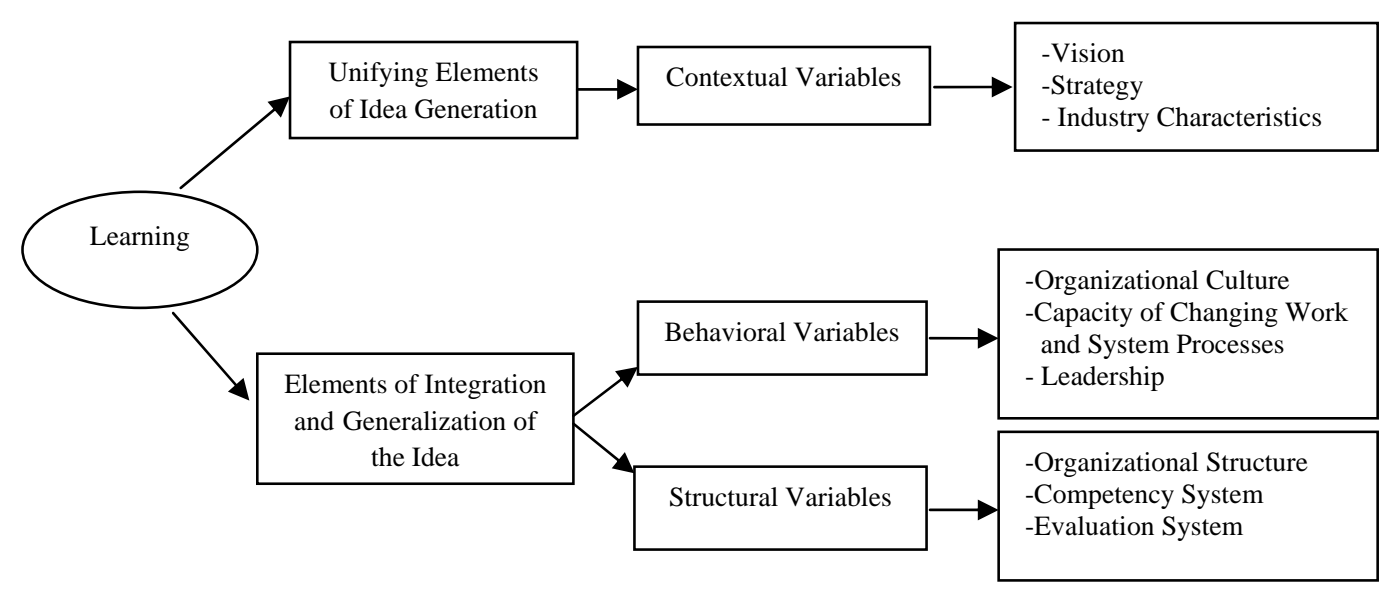

Figure 2. Organizational learning capability based on Taslimi and Naderi Khorshidi model (2002)

According to Senge (1990), a learning organization exhibits five main characteristics, namely systems thinking, personal mastery, mental models, shared vision, and team learning. Personnel mastery means that individuals learn to develop their own personal capacity to create and achieve most desired results. These employees encourage their fellow employees to improve their capacitates to attain their desired goals through creating organizational environment. Mental models are an explanation or reflection of the individuals' internal pictures of the world which continually modifying and clarifying our personal vision. Individuals through shared vision develop a sense of shared responsibility within organizational groups by providing common pictures of their desired future and establishing 
a set of guiding principles and practices to support it. Another characteristic, team learning, involves relevant communication skills and collective thinking which focuses on increasing team's intelligence and abilities which is more than the sum of team member's talents. A system thinking which forms the systems consists of a way of thinking, language for describing and understanding other forces, principles, and their interactions. This kind of thinking creates a shared vision both in team or organization level (Ghorbanizadeh, 2008).

\section{Network Pattern of Learning Organization}

Learning organization is more than an adaptive and transactional organization. In other words, it is a transformational organization which involves all individuals in creating, deploying, and transferring knowledge, improving organizational performance through team learning, and enhancing the capacity to create their own future. The transformational nature of learning organization requires an organizational plan that focuses on the structure of organizational components and their interrelationships. Figure 3 presents Daft's (2013) view about learning organizational design and its components.

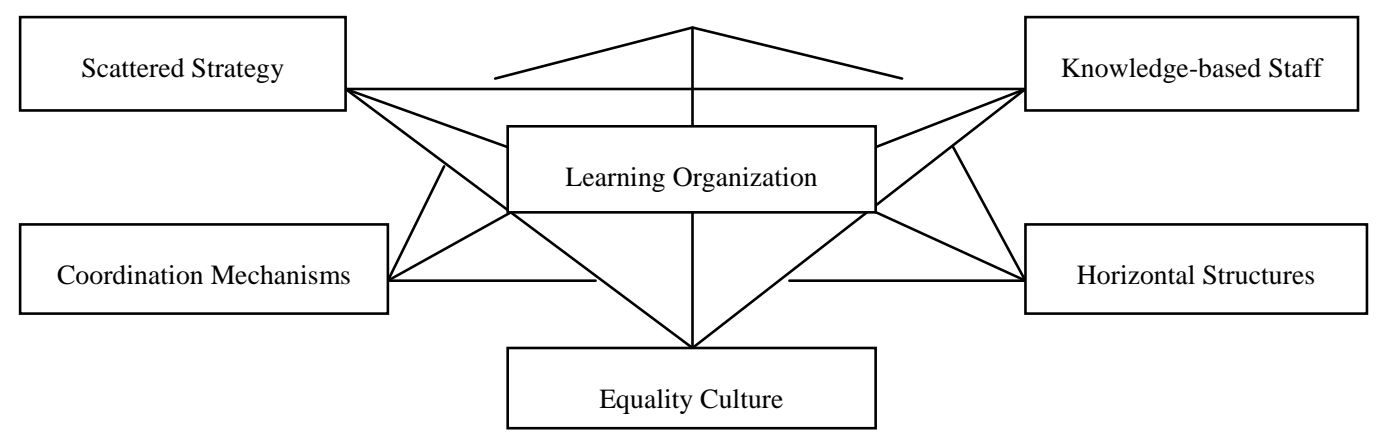

Figure 3. Network pattern of learning organization (Daft, 2013)

\section{Characteristics of Learning Organization}

Grigor (2005) proposed predictive of learning organization by combining the learning organization profile developed by Marquardt (1996) and learning organization profile. Its components include training and retraining, bonuses and retraining, information flow, visions and strategies, and individual and group development. Learning organization profile consists of the systems such as dynamics of learning at the individual, group, and organizational levels, organizational changes including the vision, culture, strategy, structure, and capabilities of staff, knowledge management processes including acquisition, creation, 
storage or marketing, transport and use of technology and information systems (Abu Khadra \& Rawabdeh, 2006). There is a deep connection between different parts and components of these systems in learning organizations.

Drucker (1988) described these organizations as an orchestra in which anyone plays his own instrument. The important point is that there is a deep connection between all musicians and the conductor which results in rhythmic music. Despite having large number of employees, the nature of modern learning organizations such as IBM and Microsoft have grown enormously. Another feature of learning organizations is streamline of information flow within an organization which leads to sustainable knowledge and human resource management development in these organizations. Organizational intelligence and productivity will be improved with the growth of personnel knowledge. The personal in these organizations improve their own existing knowledge and skills due to regular recurrent trainings and personal devolution by building multiple teams and discussion groups. Such processes provide an understanding of the meaning of dominant cultures and goals and create a shared vision or goal between human resources and organization. The existence of a charismatic and strong leader provides a basis for developing a shared vision and building goals. In this case, the organization's overall strategy sets the general direction of the organization from bottom to top, creates a shared vision for personal, and openly flows the information. This information makes logical connection between different highly skilled sectors. Atafar and Bahrami Samani (2009) conducted a research in state and Azad universities of Shahrekord based on Senge's model. The results revealed that learning organization components implemented in state universities were lower than average and in Azad universities were higher than average and both state and Azad universities' current conditions were far away from the expected and desired conditions.

\section{Research Hypotheses}

The study specifically aimed to answer the following research hypotheses:

$\mathrm{H}_{1}$. Ardabil Social Security Hospital's situation is more than average level in the dynamic learning subsystem.

$\mathrm{H}_{2}$. Ardabil Social Security Hospital's situation is more than average level in the organizational transformation subsystem. 
$\mathrm{H}_{3}$. Ardabil Social Security Hospital's situation is more than average level in the people enforcement subsystem.

\section{Method}

This study adopted a cross-sectional survey research design. The participants of the study consisted of 234 employees working at Ardabil Social Security Hospitals. A learning organization questionnaire developed by Marquardt (2002) was used to measure dimensions of learning organization based on Likert's scale with a Cronbach's alpha coefficient of 0.87. To confirm the validity of the questionnaire, the researchers asked two experts in the field to rate the instrument's efficacy in terms of how effectively it measures informants' learning. The questionnaire consisted of four sections. The first section of the questionnaire related to the demographic profiles of selected participants, entailing basic information on identities, such as age, gender, occupation, education, and previous work experience. Other three sections, each section included 10 items, asked questions about three subsystems of learning organization, namely dynamic learning, organizational transformation, and people enforcement. It intended to gauge the perceptions of employees regarding these subsystems at a particular point in time. Participants were instructed to rate themselves using a five point Likert-Scale ranging from strongly disagree (1 point) to strongly agree (5 points).

\section{Result}

The first hypothesis in this study was whether Ardabil Social Security Hospital's situation is more than average level in the dynamic learning subsystem. Table 1 summarizes the descriptive results of employees’ dynamic learning.

Table 1

Results of Descriptive Statistics of Dynamic Learning

\begin{tabular}{llcc}
\hline Group & $\mathrm{N}$ & Experimental Mean & Theoretical Mean \\
\hline Employees & 234 & 4.32 & 3 \\
\hline
\end{tabular}

Table 2 shows the results of one sample t-test for the total dynamic learning sub-system. As can be seen in Table 2, the situation of dynamic learning subsystem among employees of Ardabil Social Security Hospital was more than average level. According to mean differences which was a constant and positive quantity ( $\mathrm{MD}=1.32)$, the theoretical or population mean was more than three $(\mu>3)$. The lower and upper intervals were positive 
values, therefore with 95\% confidence interval the mean differences were a positive quantity more than zero. The $t$ value for dynamic learning subsystem was equal to 54.94 and the significant value (0.00) was less than 0.05. Based on these data, the first hypothesis which stated that the Ardabil Social Security Hospital's situation in the dynamic learning subsystem is more than average level was confirmed.

Table 2

One Sample T-test for the Total Dynamic Learning Sub-system

\begin{tabular}{lcccccc}
\hline Variable & \multicolumn{5}{c}{ T-test for Equality of Means } \\
\cline { 2 - 7 } $\begin{array}{l}\text { (Dynamic } \\
\text { Learning) }\end{array}$ & $\begin{array}{c}\text { Sig. } \\
\text { (2-tailed) }\end{array}$ & $\mathrm{t}$ & $\mathrm{df}$ & Mean Differences & 95\% Confidence Interval of the Difference \\
\cline { 3 - 7 } & & & & & Lower & Upper \\
\hline Employees & 0.00 & 59.94 & 233 & 1.32 & 1.43 & 1.38 \\
\hline
\end{tabular}

To test the second hypothesis, descriptive statistics are used at the onset of the study. Table 3 demonstrated the descriptive statistics of organizational transformation. For more meticulous analysis, the researcher ran one sample t-test.

Table 3

Results of Descriptive Statistics of Organizational Transformation

\begin{tabular}{lccc}
\hline Group & $\mathrm{N}$ & Experimental Mean & Theoretical Mean \\
\hline Employees & 234 & 2.89 & 3
\end{tabular}

Table 4 illustrates the results of one-sample t-test for the total organizational transformation sub-system. As shown in Table 4, the employees't-value and p-value $t$ (233) $=-1.96, p=0.15>0.05$ ) were not considered to be statistically significant. That is, the determined $p$-value $(0.15)$ is higher than significance level $(0.05)$. So, it could be concluded that the test was meaningless and there was no significant difference between the experimental and the theoretical means in Ardabil Social Security Hospital according to the subsystem of organizational transformation. The magnitude of mean differences was a negative quantity ( $\mathrm{MD}=-1.11$ ), therefore the theoretical or population mean was less than three $(\mu<3)$. The lower and the upper intervals respectively are shown in Table 4 . Based on these data, the second hypothesis which stated that Ardabil Social Security Hospital's situation is more than average level in the organizational transformation subsystem was rejected.

Table 4 
One Sample T-test for the Total Organizational Transformation Sub-system

\begin{tabular}{lcccccc}
\hline Variable & \multicolumn{3}{c}{ T-test for Equality of Means } \\
\cline { 2 - 6 } $\begin{array}{l}\text { (Organizational } \\
\text { Transformation) }\end{array}$ & $\begin{array}{c}\text { Sig. } \\
\text { (2-tailed) }\end{array}$ & $\mathrm{t}$ & $\mathrm{df}$ & Mean Differences & \multicolumn{2}{c}{$\begin{array}{c}\text { 95\% Confidence Interval } \\
\text { of the Difference }\end{array}$} \\
\hline Employees & 0.15 & -1.96 & 233 & -0.11 & Lower & Upper \\
\hline
\end{tabular}

Table 5 summarizes descriptive results of employees’ people enforcement.

Table 5

Results of Descriptive Statistics of People Enforcement

\begin{tabular}{lccc}
\hline Group & $\mathrm{N}$ & Experimental Mean & Theoretical Mean \\
\hline Employees & 234 & 3.87 & 3
\end{tabular}

Table 6 illustrates the results of t-test for the employees of Ardabil Social Security Hospital. As shown in this table, $t$-value and $p$-value were $(\mathrm{t}(233)=32.02, p=0.00<0.05)$ considered to be statistically significant.

Table 6

One Sample T-test for People Enforcement Sub-system

\begin{tabular}{|c|c|c|c|c|c|c|}
\hline \multirow{3}{*}{$\begin{array}{c}\text { Variable } \\
\text { (People } \\
\text { Enforcement) }\end{array}$} & \multicolumn{6}{|c|}{ T-test for Equality of Means } \\
\hline & \multirow{2}{*}{$\begin{array}{c}\text { Sig. } \\
\text { (2-tailed) }\end{array}$} & \multirow[t]{2}{*}{$\mathrm{t}$} & \multirow[t]{2}{*}{$\mathrm{df}$} & \multirow[t]{2}{*}{ Mean Differences } & \multicolumn{2}{|c|}{$\begin{array}{l}\text { 95\% Confidence Interval of the } \\
\text { Difference }\end{array}$} \\
\hline & & & & & Lower & Upper \\
\hline Employees & 0.00 & 32.02 & 233 & 0.87 & 0.93 & 0.82 \\
\hline
\end{tabular}

The magnitude of the differences between theoretical and experimental means of employees was a positive quantity $(\mathrm{MD}=0.87)$. The lower and the upper intervals were 0.93 and 0.82. Based on these data, the third hypothesis which stated that Ardabil Social Security Hospital's situation is more than average level in the people enforcement subsystem was confirmed.

\section{Discussion and Conclusion}

The main purpose of the present study was to examine the implementation of learning organization subsystems based on Marquardt systematic model in Ardabil Social Security Hospital. The major findings of the study revealed that Ardabil Social Security Hospital did not place in a suitable position regarding to its organizational transformation, while there was not a significant difference between predicted means of two learning organization's subsystems, namely dynamic learning and people enforcement and their actual mean. 
Regarding to learning organization characteristics, there was a significant difference among employees.

According to the findings of the study, we can implement the characteristics of a learning organization in mentioned dimensions in Ardabil Social Security Hospital by providing appropriate ground for improving these subsystems which guide this company to achieve these characteristics. The study by Yaghoubi, et al. (2010) revealed that the application of learning organization subsystems was average in educational hospitals of Isfahan University of Medical Sciences. Furthermore, it showed that there was a significant relationship between learning organization and organizational commitment and between learning organization and job experience. To date, the findings of studies revealed that the current status of implementation of learning organization components in the educational system of our country was average or lower than average and were far away from desired or ideal situation (Arasteh \& Enayati, 2010; Ghahremani, 2001; Mahmoudzadeh, 2005; Pardakhtchi, Ahmadi, \& Arezumandi, 2007). As the findings of this study suggest, the theories and concepts about learning and organizational learning in diverse dimensions should be noted to create a learning organization in any organization. Furthermore, in learning organization as a knowledge-based organization, knowledge management can play a vital role in supporting learning and learning organization through sharing the effectiveness of knowledge in an organization. The most valuable asset of any organization is its human resources and if the organization is supposed as a learning organization, all its employees need to commit themselves to the organizational targets and fully develop their learning potentials in required time. Also, factors affecting organizational learning and learning organization as predisposing factors should be viewed as effective factors for creating a learning organization and implementing its features.

The present study is not free from limitations. The very first limitation of the study relates to using only Ardabil Social Security Hospital's employees and excluding other private and public hospitals or other organizations. Second, this analysis can be expanded to incorporate additional learning organization subsystems. Third, this study used a standard learning organization questionnaire to elicit information from employees. The use of other methods such as observation and interview could have increased the validity of data. Fourth, the number of participants of this study can hardly be generalized to the whole population of different hospitals in Iran. Fifth, learning organizations are less discovered and more 
described. The variety of the features mentioned by the experts has hindered the arrival at the desirable consensus about the assessment method of organizational learning process and identification of learning organization. Sixth, this study used Marquardt systematic model, it could have benefited from other learning organization questionnaires such as learning organization dimensions questionnaire of Watkins-Marsick. Finally, the sample of the study was employees in one hospital, future studies can be conducted in other higher education institutions and administrative offices among administrators and professional staff. In order to strengthen and back up the findings and conclusions in this study, it is essential to implement further research in analyzing the factors affecting learning organizations.

\section{References}

Abu Khadra, M. F., \& Rawabdeh, I. A. (2006). Assessment of development of the learning organization concept in Jordanian industrial companies. Journal of Learning Organization, 13 (5), 455-474.

Argyris, C. (1999). On organizational learning (2nd ed.). Oxford: Blackwell Publication.

Arasteh, H. R., \& Enayati, T. (2010). Evaluating the Islamic Azad Universities based on the characteristics of the learning organizations: Case studies of Guilan and Mazandaran branches. Iranian Journal of Higher Education, 2(3), 47-65.

Atafar, A., \& Bahrami Samani, M. (2009). The amount of using the components of learning organization at the state and Azad Islamic universities. Journal of Higher Education Association of Iran, 1,161-179.

Brown, J. S., \& Duguid, P. (1991). Organizational learning and communities of practice: Toward a unified view of working, learning and innovation. In E. L. Lesser, M. A. Fontaine, \& J. A.

Slusher (Ed.), Knowledge \& communities. Oxford: Butterworth Heinemann.

Conner, D. R. (1992). Managing at the speed of change: How resilient managers succeed and prosper where others fail. New York: Villard Books.

Daft, R. L. (2007). Principles of organization theory and design (M. Arabi \& A. Parsayan, Trans).Tehran: Cultural Research Bureau.

Daft, R. L. (2008). Organizational theory and design ( $10^{\text {th }}$ ed.). USA: South-Western Cengage Learning.

Daft, R. L. (2013). Organization theory and design ( $11^{\text {th }}$ ed.). Mason, OH: South-Western.

Dodgson, M. (1993). Organizational learning: A review of some literatures. Organization Studies, 14(3), 375-394.

Drucker, P. F. (1988). Management and the world’s work. Harvard Business Review, 66, 65-76.

Fiol, C. M., \& Lyles, M. A. (1985). Organizational learning. Academy of Management Review, 10(4), 803-813.

Garavan, T. (1997).The learning organization: A review and evaluation. The learning organization, 4(1), 18-29.

Garvin, D. A. (2000). Learning in action: A guide to putting the organizational learning to work. Boston: Harvard Business School Press.

Ghahremani, M. (2001). Learning organization, as the outcome of half a century of human development. Quarterly Journal of Management \& Development, 3(9), 79-90.

Ghorbanizadeh, V. (2008). Organizational learning and learner organization with approach to knowledge management. Tehran: Baztab Publication.

Jyothibabu, C., Ayesha, F., \& Bibhuti Bhusan, P. (2010). An integrated scale for measuring an organizational learning system. The Learning Organization, 17(4), 303-327.

Mahmoudzadeh, M. (2005).The assessment of different provinces' readiness to implement learning organization's characteristics at their education system in Iran (Unpublished master's thesis). Tehran: Tarbiat Modarres University.

Marquardt, M. J. (1996). Building the learning organization. New York: McGraw-Hill

Marquardt, M. J. (2002). Building the learning organization: Mastering the five elements for corporate learning ( $2^{\text {nd }}$ ed.). Palo Arto, CA: Davies-Black Publishers. 
Mirghasemi, S. R. (2006). Evaluation of the Mofid educational institution as learning organization. (Unpublished master's thesis). Allameh Tabatabaee University, Tehran.

Naderi Khorshidi, A. (2002). Designing a model for development of organizational learning capability in Iran Khodro Cooperative (Unpublished doctoral dissertation). University of Tehran, Tehran.

Owen, H. (1991). Riding the tiger: Doing business in a transforming world. Potomac, MD: Abbott Publishing.

Pardakhtchi, M., Ahmadi, G., \& Arezumandi, F. (2007). Investigating the relationship between quality of work life and job burnout among teachers and managers of Takestan town. Educational management \& leadership periodical, 3, 25-50.

Rahnavard, F. (2000).Organizational learning and learning organization. Journal of Public Administration, 43, 16-25.

Senge, P. M. (1990).The leader's New Work: Building learning organizations.Sloan Management Review, 32(1), 7-23.

Senge, P. M. (2007). The fifth order: Creating learning organization (Kamal Hedayat H., \& Roshan V., Trans). Tehran: Publication of Industrial Management Organization.

Sharman, C. (2005). Leadership and learning organization (Unpublished doctorial dissertation). University of New York Empire State College, New York.

Sobhaninezhad, M., Shahaei, B., \& Youzbashi, A. (2006). Learning organization. Tehran: Yastaroun Press.

Watkins, K. E., \& Marsick, V. J. (2004). The construct of the learning organization: Dimensions, measurement, and validation. Journal of Human Resource Development Quarterly, 24(4), 33- 45.

Yaghoubi, M., Raeisi, A. R., Afshar, M., Yarmohammadian, M. H., Hasanzadeh, A., Javadi, M., \& Ansary, M. (2010). The relationship between learning organization and organizational commitment among nursing managers in educational hospitals of Isfahan University of Medical Sciences in 2008-2009. Iranian Journal of Nursing \& Midwifery Research, 15(2), 83-89.

Yang, B., Watkins, K. E., \& Marsick, V. J. (2004). The construct of learning organization dimensions, measurement, and validation. Human Resources Development Quarterly, 15(1), 31-55. 